\title{
Nanoteknolojinin Tedavi ve Bakım Girişimlerine Yansıması*
}

\author{
The Reflection of Treatment and Care Initiatives in Nanotechnology
}

\author{
Hatice ÖNER $* *$, Hatice DEMİRDAĞ $\breve{G}^{* * *}$, Neriman AKYOLCU $* * * *$, Nevin KANAN*****
}

İletişim/ Correspondence: Hatice ÖNER Adres/ Adress: Bezmialem Vakıf Üniversitesi, Sağlık Bilimleri Fakültesi, Hemşirelik Bölümü, Adnan Menderes Bulvarı Vatan Cad. 34093, Fatih/İstanbul Tel: 0212523 22 88/1179 Fax: 02124531870 E-mail: htcnr8878@gmail.com

\section{$\ddot{O} Z$}

Nanoteknoloji, nanometre boyutlarındaki fiziksel, kimyasal ve biyolojik olayların anlaşılması amacıyla, maddenin moleküler düzeyde düzenlenmesi ve kontrol edilmesine yönelik çalışmaları kapsamaktadır. Günümüzde nanoteknoloji çalışmaları, birçok alanda olduğu gibi, sağlık alanında da önemli gelişmeler göstermektedir. Nanoteknoloji'nin, insan ve insanı etkileyen sistemlerin moleküler düzeyde izlenmesi, onarılması ve yapılandırılması yoluyla insan sağllğının gelişstirilmesi, korunması ve hasta bakım kalitesinin artmasını să̆ladı̆̆ı/ sağlayacă̆ı düşünülmektedir. Yanı sıra, bazı hastalıkların erken tanı ve tedavisi için umut kaynă̆ı olabileceği de öngörülmektedir. Tüm bu yararlarının yanı sıra nanoteknolojinin insan sağlı̆̆ üzerindeki olumsuz etkileri henüz tam olarak bilinmemektedir. Bu makalede, sağllk alanında olumlu etkiler yaratabilecek, günümüzde var olan ve potansiyel nanoteknoloji gelişmeleri ile olası zararlı etkileri literatür bilgileri ışı̆̆ında ele alındı.

Anahtar Kelimeler: Nanoteknoloji, tedavi, hemşirelik bakımı, nanotıp.

\section{ABSTRACT}

Nanotechnology, in order to understand nanometer-sized physical, chemical and biological processes, includes studies for the regulation and control of matter at the molecular level. Recently, nanotechnology work, as in many areas, illustrates the significant developments in the field of health. Nanotechnology, at the molecular level to be monitored system that affect human and human being, repairing and restruction through improvement of human health protection and to increase the quality of patient care provided/would be. Besides, it is foreseen to be a source of hope for the early diagnosis and treatment of some diseases. All of these benefits, as well as the side effects of nanotechnology on human health are not yet known exactly. In this article, in the area of health could have positive effects, today in the literature on the harmful effects possible with the existing and potential developments in nanotechnology were discussed.

Keywords: Nanothecnology, treatment, nursing care, nanomedicine.

\section{GíRiş}

Günümüzde, bir ölçü birimi olan “nano”, fiziksel bir büyüklüğün milyarda biridir ve genellikle "metre" ile birlikte kullanılmaktadır. Bir nanometre içerisine, yaklaş1k olarak 3-5 atom dizilebilmekte ve nano ölçekli bir malzeme yaklaşık 100-1000 atomun yan yana gelmesiyle oluşmaktadır (Karateke, Güngör ve Demir 2010; Kayır ve Bağçıl 2010; Singh 2005; Wang

\footnotetext{
*Nöroşirürji Hemşireliği Derneği 10. Bilimsel Kongresi’nde panel konuşmasl olarak sunulmuştur (4-8 Nisan 2014, Antalya), **öğr. Gör. Bezmialem Vakıf Üniversitesi, Sağllk Bilimleri Fakültesi, Hemşirelik Bölümü, ***Uzman Hemşire Üsküdar Devlet Hastanesi, ****Prof. Dr. İstanbul Üniversitesi Florence Nightingale Hemşirelik Fakültesi
}

Yazının gönderilme tarihi: 15.10.2015

Yazının basım için kabul tarihi: 16.05.2016 
2004). Genel anlamda nanoteknoloji, atom ya da hücre boyutundaki fiziksel, kimyasal ya da biyolojik yapıların incelenmesi, kontrol edilmesi, özellik ya da fonksiyonlarının değiştirilmesi olarak tanımlanmaktadir (Wang ve Tepper 2014).

Son y1llarda nanoteknoloji, dünyada ve ülkemizde önemli ve öncelikli alan olarak ilan edilmiş ve büyük oranda yatırımlar yapılmıştır (Atlı-Şekeroğlu 2013). Nanoteknoloji elektronik, ulaşım, enerji, tekstil ve tarım gibi alanların yanı sıra, sağlık alanında da etkisini göstermektedir. Nanoteknolojinin tıp alanındaki uygulamaları nanotıp olarak adlandırılmaktadır (Syed, Zubair ve Frieri 2013; Yula ve Deveci 2010). Nanotıp uygulamalarının, insan sağlığının geliştirilmesi, korunması ve hasta bakım kalitesinin artmasını sağladığı ve/ veya sağlayacağı düşünülmektedir. Örneğin, tekstil alanındaki su geçirmez, antibakteriyal, antifungal, yanmaz vb. özellikler kazandırılmış ürünlerin kullanımı hasta bakımına da büyük ölçüde katkı sağlayabilecektir. Nanomoleküller ile ilaçların sağlıklı dokulara zarar vermeden hedefe ulaşabileceği, dolaşıma gönderilecek nanorobotlarla damar lümenindeki lipitlerin uzaklaştırılabileceği, immün sistemin güçlendirilerek infeksiyonların çok kısa sürede tedavi edilebileceği, kanser gibi bazı hastalıkların erken tanı ve tedavisinin mümkün olabileceği de belirtilmektedir (Atl1-Şekeroğlu 2013; Kumar, Yadav, Goel, Moshahid ve Rizvi 2009; Nehru ve Singh 2008; Şenel 2009). Aynı zamanda nanoteknolojinin insan yeteneklerini geliştirmek için kullanılabileceği, insan hafızasının arttırılabileceği, kemiklerin sağlamlaştırılabileceği, görüş keskinliğinin arttırılabileceği ve insan ömrünün uzatılabileceği savunulmaktadır (Kuruca 2012). Kullanıldığı her alanda, heyecan verici gelişmelere katkı sağlamasının yanında, nanoteknolojinin insan sağlı̆̆ üzerine olumsuz etkileri henüz açıklığa kavuşmamıştır (Dağ 2014).

$\mathrm{Bu}$ makalede, nanoteknolojinin sağlık alanındaki var olan ve gelecekteki uygulamalarının yanı sıra, insan sağlığı üzerinde yaratabileceği olumsuz etkileri, literatür bilgileri doğrultusunda sunuldu.

\section{NANOTEKNOLOJININ TANIMI VE TARIHHÇESI}

Nanoteknoloji; Yunanca "nannos-küçük yaşlı adam veya cüce” ve "tekhné-el işi veya sanat" ve "logia-bir konunun çalışılması" kelimelerinin bir araya gelmesiyle oluşmaktadır. Genel olarak nanoteknoloji, atom boyutundaki maddelerde ya da 100 nanometreden küçük yapılarda gerçekleştirilen işlem, ölçüm ve düzenleme çalışmaları olarak tanımlanmaktadır (Celep ve Koç 2008; Erol-Demirbilek 2015; Kayır ve Bağç1l 2010; Singh 2005; Wang 2004).

Nanoteknoloji ile ilgili çalışmaların, 1960’lı yıllarda başladığı görülmektedir. Bu çalışmaların başlangıcında, 20. yüzyılın ünlü fizik bilim adamlarından biri olan Richard Phillips Feynman'ın 1959 yılında, malzeme ve cihazların moleküler boyutta üretilmesi ile başarılabilecekler üzerine yaptığı konuşmasına (Aşağıda daha çok yer var/ There is Plenty of Room at the Bottom) dayandığı bilinmektedir (Kayır ve Bağçı1 2010; Ünlü 2009). Feynman bu konuşmasında, malzeme boyutlarının küçültülmesi ile çok küçük yapıların ölçülebileceği ve yeni amaçlar için kullanılabileceğinin altını çizmiştir. Daha sonraki yıllarda bilim adamları, Feynman'ın açıklamaları doğrultusunda, daha küçük yapılar üzerinde çalışmaya başlamışlardır. Ancak boyutlar küçüldükçe, yapılan çalışmaların izlenmesinde güçlük yaşanması nedeniyle, 1981 yılında Uluslararası İş Makinaları (International Business Machines-IBM) tarafından yeni bir mikroskop türü olan "Taramalı Tünellemeli Mikroskop" (Scanning Tunneling Microscope, STM) geliştirilmiştir (Kayır ve Bağçıl 2010; Ünlü 2009). Nanoteknoloji alanında önemli katkıları bulunan Eric Drexler, 1980'lerin ortasında nanoteknolojinin olası uygulamalarını anlattığı "Yaratma Motorları (Engines of Creation)" isimli kitabını yayımlamıştır. Drexler, atomların planlı olarak sıralanmasıyla maddenin fiziksel özelliklerinin değiştirilebileceğini ve istenen özelliğe sahip moleküllerin oluşturulabileceğini öngörmüştür. Örneğin; elmas, kömür ve grafit aynı atomlardan ve karbondan olmasına karşın fiziksel özellikleri birbirlerinden çok farklıdır. Yani, atomların sıralanışlarının düzenlenmesi ile istenen özellikte madde oluşturulabileceği vurgulanmıştır (Şenel 
2009). Buradan yola çıkarak yapılan çalışmalarla birlikte 1990’lı y1llara, bir nanometre büyüklügünde çelikten daha güçlü, plastikten daha hafif, elektrik ve 1S1 geçirgen bir yapıya sahip olan Fullerene molekülünün damga vurduğu görülmektedir. Aynı zamanlarda Japon bilim adamları, Fullerene molekülü ile benzer ancak daha esnetilmiş bir şekli olan nanotüpleri bulduğunu duyurmuştur.

Son yıllarda, dünyada nanoteknoloji ile ilgili gelişmelere bakıldığında, 1999 yılında Amerika Birleşik Devletleri'nde nanoteknoloji alanında yürütülen araştırma, geliştirme ve ticarileştirme faaliyetlerinin hızı$\mathrm{n}$ ı artırma amacı taşıyan ilk resmi hükümet programı, "Ulusal Nanoteknoloji Adımı” başlamıştır. 2001 yılında Avrupa Birliği, nanoteknoloji çalışmalarını öncelikli alan olarak ilan etmiştir. Japonya, Tayvan, Singapur, Çin, İsrail ve İsviçre benzer programlar başlatarak 21. yüzyılın ilk küresel teknoloji yarışında önlerde yer almak için çalışmalarına hız vermiştir (Kayır ve Bağçıl 2010; Ünlü 2009). Ülkemizde ise, 1960'larda “Planlı Dönem” ile başlayan bilim ve teknoloji programları, Türkiye Bilimsel ve Teknolojik Araştırma Kurumu (TÜBİTAK) bünyesinde geliştirilmektedir. 2001 yılında, Türkiye'nin 2003-2023 yılları için Bilim ve Teknoloji Stratejileri'nin belirlendiği VİZYON 2023 projesinin başlatılmasına karar verilmiştir (Ünlü 2009). Yanı sıra, nanoteknolojinin birçok alanda öneminin anlaşılması ile birlikte, ülkemizde nanoteknoloji çalışmalarını desteklemek ve güncel uygulamaları yakalayabilmek için, temel olarak devlet destekli merkezler kurulmaya başlamıştır. Ayrıca, birçok üniversite bünyesinde (Örn; Bilkent Üniversitesi vb.) nanoteknoloji araştırma merkezleri kurulmuş ve bu alanda çalışmalara hız verilmiştir (Çıracı ve ark. 2005).

\section{NANOTEKNOLOJININ AMAÇLARI VE KULLANIM ALANLARI}

Nanoteknolojinin en büyük avantajı, moleküler düzeyde çalışılabilmesidir. Nanoteknoloji ile atomların istenilen şekilde düzenlenmesi, her alanda daha küçük, daha dayanıklı, daha hafif maddelerin oluşturulmasına ve üretimlerin doğaya daha az zarar vermesine olanak sağlayabilecektir (Karateke ve ark. 2010). Nanoteknoloji;

- Nanometre ile ölçülebilen yapıların analizinin yapilmasi,

- Nanometre boyutunda yapıların fiziksel özelliklerinin araştırılması,

- Malzemelere daha üstün özellikler kazandırılması,

- Daha dayanıklı, daha hafif, daha hızlı yapılar sağlama,

- Daha az malzeme ve enerji kullanımı, gibi amaçlara hizmet etmektedir (Bozkaya 2011; Turgut, Keskin ve Avşar 2010).

Günlük yaşamda nanoteknolojinin, elektronik, manyetik, optik, mekanik ve biyomedikal amaçlı işlemler gibi geniş bir uygulama alanı bulunmaktadır. Bunların yanı sıra sağlık alanında da nanoteknoloji uygulamaları oldukça hız kazanmıştır. Özellikle, cerrahi nanorobot, nanoaygıt ve nanopartiküllerin hastalıkların tanı ve tedavi uygulamalarına; nanoteknoloji ile tasarlanmış tekstil malzemeleri gibi ürünlerin de insan sağlı̆̆1nın gelişmesi, korunması ve hasta bakım uygulamalarına önemli ölçüde katkı sağlayacağı düşünülmektedir (Bozkaya 2011; Dağ 2014; Syed ve ark. 2013; Yula ve Deveci 2010).

\section{SAĞLIK ALANINDA NANOTEKNOLOJI UYGULAMALARI}

\section{Malzemelerin Yüzey ve Kaplamalarında Nanoteknoloji Uygulamaları}

Bir malzemenin sahip olacağı yüzey özellikleri (Örn; sürtünme, yapışma, suyu sevme ya da sevmeme, biyolojik etkileşim vb.), nanometre boyutundaki en üst tabakasının kimyasal yapısı tarafindan belirlenmektedir. $\mathrm{Bu}$ nedenle, bir malzemenin var olan özelliğinin geliştirilmesi ya da yeni özellik kazandırılması yüzey özelliğinin değişmesi ile ilişkilidir. Malzemelerin yüzey alanı ile ilgili konularda çalışan bilim adamları, özellikle Asya'daki bazı dinlerde temizlik ve safl1ğın simgesi olan Lotus bitkisinden ilham almışlardır. Lotus bitkisi, çamurlu nehir ve göllerde yetişmesine karşın, yüzeyindeki mikron ve tepecikli yapılar ve toprağa eğimli yapısıyla yüzeyinde su ve kir tutma- 
maktadır. Lotus'un bu özelliğinden yola çıkan bilim adamları kumaş, cam vb. birçok yüzeye florlu ya da silikon içeren bileşiklerle işlem uygulayarak su ve kir tutmama özelliği kazandırmışlardır (Bozkaya 2011; Çıracı ve ark. 2005). Bu yolla tekstil ürünlerine çok fazla su çeken, su geçirmez, leke tutmaz, buruşmaz, antibakteriyal, antifungal, yanmaz vb. özellikler kazandırılmış ve bu ürünlerin kullanımı yaygınlaşmaya başlamıştır (Celep ve Koç 2008; Üreyen 2007). Hasta bakımında kullanılan suyu çok çeken (süperhidrofilik) yüzeyli malzemelere kontak lens temizleyicileri, sslak vücut temizleme mendilleri ve çocuk/ hasta bezleri örnek olarak gösterilmektedir (Bozkaya 2011; Çıracı ve ark. 2005). Yatağa bağımlı hastalarda özellikte suyu çok çeken tekstil ürünlerinin (Örn; nevresim, çarşaf, yastık kılıfı vb.) kullanılmasının, hasta konforu ve bakım kalitesinin artmasına yardımcı olacağ 1 düşünülebilir. Yanı sıra, bu tekstil ürünlerinin yüzeyleri, spesifik nano parçacıklardan oluşan ince bir tabaka ile kaplanarak yapışma, sürtünme ve aşınmaya dirençli hale getirilebilmektedir. Böylece uzun süreli yatağa bağımlı hastalarda, basınç yarası oluşmasını önlenmesine katk1 sağlayabilir. Suyu sevmeyen ya da su itici (hidrofobik) özellikteki yüzeye sahip malzemelere ise tekstil ürünleri yüzeyi ve cam yüzeyler örnek verilebilmektedir. Bu malzemelerden üretilen ameliyathane malzemelerinin özellikle cerrahi girişimlerde sterilitenin sürdürülmesine yardımcı olabileceği düşünülebilir. Yanı sıra, gözlük kullanan bireylerde su tutmayan cam yüzeyler ile tasarlanmış gözlükler, hasta konforunu arttırabilmektedir (Bozkaya 2011; Çıracı ve ark. 2005). Benzer şekilde çorap ipliğinin gümüş nanoparçacıklar ile katkılandırılması, çorap içerisinde bakteri gibi mikroorganizmaların yaşaması ve çoğalmasını engelleyebilmektedir. Bu çoraplar özellikle diyabeti olan hastaların ayak sağlığını korumaya önemli ölçüde katkı sağlayabilmektedir.

Yüzeylerin korunması ve bozulmanın önlenmesi için önemli yöntemlerden biri de nanoteknoloji ile tasarlanmış koruyucu kaplama teknolojisidir (Bozkaya 2011; Çıracı ve ark. 2005). Üstün mekanik özelliklere sahip olan metal nanopartiküller ve alaşımları, iskelet- kas sisteminin mekanik koşullarına kolaylıkla uyum gösterebilen malzemelerdir. Kobalt krom alaşımları eklem protezi ve kemik yenileme malzemesi olarak ortopedik uygulamalarda, çene cerrahisinde dolgularda ve diş implantlarında, kalp damar cerrahisinde özellikle stent uygulamalarında yaygın bir şekilde kullanılmaktadır (Atl1-Şekeroğlu 2013; Bozkaya 2011; Çıracı ve ark. 2005).

\section{Nanoteknoloji ve Beslenme}

Gıda alanı, nanoteknolojinin önemli gelişmeler sağlayacağı düşünülen alanlardan biridir. Nanoteknolojik çalışmalar ile gıdaların hazırlanması, paketlenmesi, besin kalitesi ve gida güvenliğinde önemli gelişmeler sağlanabilecektir (Erol-Demirbilek 2015; Tarhan, Gökmen ve Harsa 2010).

Doğada, gıda molekülleri nano ölçek boyutlarında bulunmaktadır. Nanoteknoloji ile gıda içeriğindeki bu moleküllerin istenen özelliklere göre tasarlanarak kontrol edilebileceği, yanı sıra nano ölçekte yiyecekler elde edilebileceği belirtilmektedir (Dağ 2014; Erol-Demirbilek 2015). Luo, Pan ve Zhong (2015)'un yaptıkları bir çalışmada; sodyum kazeinat (hayvansal protein) ve pektinin (sakkarit) nano parçacıklarını ürettiklerini ve oral yoldan nanokomplekslerin kullanılabileceği belirtilmiştir. Bunun dışında, gıdalara farklı renk, aroma ve besin ögesi taşıyan nanoyapıların eklenmesiyle özellikleri değiştirilerek yeni ürünlerin geliştirilebileceği öngörülmektedir. Ayrıca, gıda ürünlerinin korunması ve raf ömrünün uzatılması amacıyla üretilen nanokompozitlerle ambalajlama ve nanosensörler ile gıdalardaki patojenlerin belirlenmesi ile gıda güvenliği konusunda da etkili olabileceği belirtilmektedir (Dağ 2014).

\section{Nanotip}

Tıp biliminde nanoteknoloji çalışmaları, "nanotıp" olarak adlandırılmaktadır (Syed ve ark. 2013; Yula ve Deveci 2010). Nanoteknolojinin tıp biliminde kullanım amacı, hücre fonksiyonlarını kontrol altında tutarak hastalıkların önlenmesi, erken tanı ve tedavisi, yara iyileşmesi, vücudun moleküler bilgilerinin kulla- 
nılabilmesi, sağlığın geliştirilmesi ve korunması amacryla moleküler araçlar üretilmesini kapsamaktadır (Kuruca 2012; Langer ve Weissleder 2015; Syed ve ark. 2013; Yula ve Deveci 2010).

Günümüzde kullanılan tıbbi yöntemler hücre düzeyinde etkili olamadığından, bazı hastalık ve yaralanmaların tanı ve tedavisinde güçlük yaşanmaktadır. Bu amaca yönelik, nanoteknoloji ile biyomedikal ve tıp alanlarında; akıllı ilaç taşıyıcıları, tıbbi görüntüleme araçları, biyosensörler, nanomakineler (biyorobotlar), implant ve yapay doku materyalleri geliştirilmekte; nükleik asit analizleri, biyoinformatik ve genomik uygulamalar için DNA çiplerinin nanofabrikasyonu, kök hücre bazlı organ mühendisliği uygulamaları ve nanocerrahi girişimler uygulanabilmektedir (Atl1Şekeroğlu 2013; Langer ve Weissleder 2015; Syed ve ark. 2013; Yula ve Deveci 2010).

Nanotıp alanında yapılan çalışmaların son yıllarda hız kazandığı görülmektedir (Turgut ve ark. 2010). Örneğin, Bilkent Üniversitesi Ulusal Nanoteknoloji Araştırma Merkezi, yara ve yanık tedavisi için nanoteknoloji tabanlı yeni bir ürün geliştirmişlerdir. Nanoteknoloji kullanılarak üretilen peptit nanofiberlerin oluşturduğu sentetik malzemeler, doğal dokuda bulunan kollajene benzer özellikler göstermektedir. Böylece, dışarıdan hormon ve büyüme faktörü eklemeye gerek kalmaksızın yeni damar oluşumu sağlanacak ve hasarl1 doku kısa sürede kendisini onarabilecektir (Çıracı 2012). Toksöz ve Güler (2009)'in yaptıkları çalışmada da, yara ve yanık nedeniyle zarar gören dokuların tedavisi için geliştirilen nano malzemeden oluşan jel, zarar gören bölgeye uygulanmış ve doku iyileşmesinin daha hızlı olduğu gösterilmiştir. Bu jelin, dışarıdan bir hormon desteği almaya gereksinim olmadan, vücudun savunma mekanizmasını harekete geçirerek yeniden damarlanma sağladığg görülmüştür.

Günümüzde nanotıp alanında, özellikle belirli doku ve organları hedef alan nanorobotlar ve sağlıklı hücreye zarar vermeden hedefe yönelik ilaç verilmesi gibi gelişmeler uygulamaları gelecekte birçok hasta için umut kaynağı olarak görülmektedir.

\section{Nanorobotlar}

Nanorobotlar, hücre içerisindeki kimyasal olayları kontrol altında tutmak, hasarlı hücre yapılarını belirlemek ya da düzeltmek, hücre için gerekli maddeleri hücre içine taşımak, atık maddeleri hücreden uzaklaştırmak gibi mikro ölçekteki görevleri yerine getirmek için kullanılacak nano ölçek boyutlarındaki robotlardir (Şenel 2009).

Nanorobotların, insan vücudunda eksik olan vitamin, hormon, enzim veya sitokinleri üretebilme, damar hastalıklarına neden olan lipitleri uzaklaştırılabilme, immünsistemi güçlendirme, toksin ya da sindirilemeyen hücre kalıntıları gibi zararlı maddeleri ortadan kaldırma gibi özelliklerinin olacağı öngörülmektedir (Atl1-Şekeroğlu 2013; Roberts ve Freitas 2005a; Robert ve Freitas 2005b). Bunun yanı sıra, içerisine kimyasal madde yüklenen nanorobotların vücutta istenen bölge ya da hücreye gönderilmesiyle, kimyasal maddenin yalnızca istenen alanda etki göstermesi sağlanabilecektir. Böylece, kimyasal maddenin diğer organ ya da hücreler üzerindeki olumsuz etkilerinin engellenebileceği öngörülmektedir (Şenel 2009; Roberts ve Freitas 2005a). Nanorobotlardan daha etkin sonuçlar elde etmek ve vücudun reddetme (rejeksiyon) olas1lığını azaltmak için, elmas gibi dayanıklı malzemeler kullanılarak üretilecektir. Tıbbi kullanım amaçlı mikro robot geliştirme çalışmaları 2000'li yılların başlarından bu yana hız kazanmış olsa da henüz deney aşamasındadır. Ancak bu teknolojinin, önümüzdeki yıllarda gelişeceği ve nanopartiküllerin tanı ve tedavi amaçlı olarak kullanılabileceği öngörülmektedir (Robert ve Freitas 2005a). Özellikle respirosit, mikrobivar ve tektodendrimer gibi nanorobotların insan sağlığı açısından oldukça önemli olacağı vurgulanmaktadır.

Respirositler: Laboratuvar ortamında eritrositlere benzer şekilde oluşturulan respirositler küre şeklinde, 18 milyar atomdan oluşan, 1 mikron çapındaki nanorobotlardır. Respirositlerin yüzeyinin elmas kaplı olması yüksek basınca dayanıklı olmasını sağlamaktadır. Bu özelliği ile eritrositlerden yaklaşık 236 kat daha fazla oksijen taşıyabilecek olan respirositler, 
özellikle oksijen $\left(\mathrm{O}_{2}\right)$ ve karbondioksiti $\left(\mathrm{CO}_{2}\right)$ vücutta kontrollü bir şekilde dağıtmak üzere geliştirilmiştir. Respirositler, yüzeyinde bulunan $\mathrm{O}_{2}$ ve $\mathrm{CO}_{2}$ düzeyini algılayan ve gaz alışverişini sağlayan özel bir düzeneğe sahip algılayıcı yoluyla, akciğerdeki gaz alışverişini gerçekleştirebilecektir. Kan yoluyla dokulara ulaştıklarında ise, dokulardaki düşük oksijen düzeyini algılayarak içerisindeki $\mathrm{O}_{2}$ 'yi dışarı verecek, dokulardaki $\mathrm{CO}_{2}$ 'yi de içine alacaktır. Beş trilyon nanorobot içeren 5 ml'lik respirosit solüsyonu, 5.4 litre kanın taşıyabileceği kadar oksijen ve karbondioksit taşıyabilir. Böylece, çok az miktarda bir solüsyon ile daha yüksek konsantrasyonda eritrosit desteği sağlanabilecek ve akciğer kapasitesinin arttırılması üzerine oldukça etkili olabilecektir (Robert ve Freitas 2005a; Robert ve Freitas 2005b; Şenel 2009). Mikrobivorlar: Kan dolaşımında bulunan patojen mikroorganizmaları yok etmek üzere geliştirilmiş olan mikrobivorlar, mekanik beyaz kan hücresidir. Mikrobivorların, fagositoz özelliklerinin makrofajlardan yaklaşık 80 kat daha fazla, yaşam süresinin daha uzun ve daha hızlı olacağı düşünülmektedir. Antibiyotik tedavisi ile haftalar ya da aylar içinde ortadan kaldırılabilecek bir septisemik infeksiyonun, mikrobivorlar yardımıyla dakikalar ya da saatler içerisinde ortadan kaldırılabileceği öngörülmektedir (Robert ve Freitas 2005a; Robert ve Freitas 2005b; Şenel 2009).

Tektodendrimerler: Hastalıklı dokuyu tanıma, hastal1ğın evresini saptama, ilaç salınımı yapma ve tedavinin sonucunu raporlama gibi işlevlerin yürütüleceği nanorobotlardır. Kanser hastalığı ve viral, paraziter infeksiyonların tedavisinde etkili olacağı düşünülmektedir (Narter 2005).

\section{Nanocerrahi}

Günümüzde gelişen teknoloji ile birlikte, cerrahi girişimin başarısını etkileyebilen vücuda daha iyi uyum sağlayan (implant vb.) ve dayanıklı malzemelerin kullanılmasının da önem kazandığı görülmektedir. $\mathrm{Bu}$ amaçla nanoteknoloji ile üretilen ortopedik protezler, kardiyovasküler, nöral, plastik ve rekonstrüktif ve dental implantlar, oftalmik sistemler, kateterler, insülin pompaları gibi ilaç veren sistemler, sütur, adhesifler ve kan yerine geçen sıvılar gibi cerrahi sistemler kullanıldığı belirtilmektedir (Çelik 2011). Yanı sıra yapılan bir çalışmada, $<1 \mathrm{~mm}$ uç çapına sahip bir hızla titreşimli $(100 \mathrm{~Hz})$ mikropipet hücrenin canlılığına zarar vermeden tek nörondan dentrit kesilmesi için kullanılmıştır (Kirson ve Yaari 2000). Yakın gelecekte, nanoteknoloji ile biyolojik moleküllere çok benzeyen yapıların oluşturulabileceği düşünülmektedir. Örneğin; nanoteknoloji kullanılarak dayanıklı ve hafif yapay kemik oluşturulabileceği, bu şekilde tedavisi zor olan kırık ve iskelet yapı bozukluklarının tedavisinin mümkün olabileceği öngörülmektedir (Şenel 2009).

Hücresel düzeyde nanocerrahi ile ilgili çalışmalar da oldukça dikkat çekicidir. Cerrahi nanorobotlar, önceden programlanarak ya da bir cerrah tarafindan yönlendirilecek şekilde tasarlanarak, direkt dolaşıma verilecek ya da bir kateter ucunda vücut boşluklarına yerleştirilebilecektir. Böylece, bir patoloji ya da hastalığ saptama, tanılama ve tedavisinde etkili olabileceği düşünülmektedir (Robert ve Freitas 2005a). Hekim tarafindan kontrol edilen bir nanorobotun, kromozom replasman tedavisi olarak adlandırılan sitocerrahi yöntemi ile hastalıklı hücrenin mevcut kromozomunun ç1kartılarak yerine sağlıklı kromozomun yerleştirilebileceği bildirilmektedir (Robert ve Freitas 2005a; Robert ve Freitas 2005b). Ayrıca kanserli hücreleri bulmak ve ortadan kaldırmak, mikrovasküler tıkanıklıkları açmak ve damar endotel hücrelerini yenilemek, invaziv olmayan doku ve organ nakli gerçekleştirmek, hasara uğramış hücre içi ve hücre dişı yapılar üzerinde moleküler onarım yapmak gibi işlevleri gerçekleştirebilecekleri de öngörülmektedir (Robert ve Freitas 2005a).

\section{Nano-Onkoloji}

Son yıllarda gelişen teknoloji ile birlikte kanserin tanı ve tedavisinde önemli ilerlemeler kaydedilmiştir. Ancak, kanserin erken tanı ve tedavisine ilişkin sorunlar halen devam etmektedir (Bölüktaş 2015; Nahcivan ve Seçginli 2015). Kanserin tanılanmasında kullanılan mevcut tanı yöntemleri ile ilişkili sorunlar nedeniyle (spektrum aralığının sınırlı oluşu, penetrasyon derin- 
liğinin yeterli olmayışı, hedef hücrelerin tam olarak odaklanamaması ve sinyal/gürültü oranın düşük olması vb.), tanı yöntemlerinin verimliliğinin azaldı $\breve{g}_{1}$ belirtilmektedir. Nanoteknoloji ile geliştirilen nanoyapıların, tek bir tümör hücresinin içerisine girebilmesi ile kanserin erken tanı ve tedavisine önemli ölçüde katk1 sağlayacağı düşünülmektedir (Oylar ve Tekin 2011).

Manyetik özellikli demiroksit içeren nanoparçacıklar, kanserin erken tanılanmasına olanak sağlayacak yöntemlerden biri olarak görülmektedir. Hedeflenen tümöre yönelik geliştirilen hücre ya da özel antikorlar, nanoparçacıklarla işaretlenmektedir. İşaretli olan hücre ya da antikorlar, hedef tümörü bularak yüzeyine yapışmakta ve tümörün belirlenmesini sağlamaktadır. Böylece, çok küçük boyuttaki tümörlerin de saptanması hedeflenmektedir (Neumaier, Baio, Ferrini, Corte ve Daga 2008). Kanserin erken tanısına yönelik geliştirilen bir diğer nanoyapı da, yarı iletken malzemeler ile üretilen nano-cantileverdir. Nano-cantilever'in üzerinde, belirli proteinlere özgü biyosensörler bulunmaktadır. Bu sensörler, ortamda ilgili proteinlerin varlığını saptamaya yardımcı olmaktadır. Bu yöntem ile kanser gelişiminin erken evrelerinde ortaya çıkan biomarkerlar algılanarak, kanserin erken dönemde tan1lanması mümkün olabilecektir (Oylar ve Tekin 2011).

Günümüzde, kontrolsüz çoğalan kanser hücrelerinin yok edilmesine yönelik uygulanan tedavi yöntemleri (radyoterapi, kemoterapi vb), sağlıklı hücrelere de zarar vermektedir. Bu durum hasta bireyde, hematolojik, gastrointestinal ve cilt sorunlarının ortaya çıkmasına neden olmaktadır (Karabacak ve Uslu 2015; Yildız 2015). Nano-onkolojideki önemli gelişmelerden biri, hedef hücreye ilaç uygulanabilmesidir. Bu yöntemle, ilaçların kanser hücrelerindeki konsantrasyonları arttırılabilirken, sağlıklı hücrelere olan zararlı etkileri en aza indirilebilecektir (Kumar ve ark. 2009; Nehru ve Singh 2008; Şenel 2009). Nano-onkoloji alanında, sağlıklı hücrenin korunduğu, yalnızca kanser hücresine etki edecek tedavi yöntemleri ile kanserli hücre çoğalmasının önlenmesine yönelik yapılan çalışmaların olumlu sonuçlar verdiği görülmektedir (Laiva ve ark.
2015; Meng ve ark. 2013; Mousavie-Anijdan, Mahdavi, Shirazi, Zarrinfard ve Haiati 2013; Sanna, Pala ve Sechi 2014). Hedef hücreye ilaç uygulama amacıyla geliştirilen nanoyapılardan olan dendrimerlerin yüzeylerine uygun bağlayıcılar yerleştirilerek, kanserli hücreler ile birleşmeleri sağlanabilmektedir. Dendrimerlerin iç boşluklarına antikanserojen ilaçlar yerleştirilerek, sağlıklı hücrelere zarar vermeden kanserli hücreler yok edilebilecektir (Oylar ve Tekin 2013). Radyoterapiye alternatif olarak, belirli bir dalga boyundaki radyasyonu absorbe ederek isınacak nanoyapılar geliştirilmiştir. Bu nanoyapılar, kanserli hücre içerisine girdiğinde, uygun dalga boyundaki radyasyon ile kanser hücresini yakabilecektir (Kumar ve ark. 2009; Nehru ve Singh 2008). Kanser tedavisi için geliştirilmiş bir diğer nano yapı nanoshell (NS)'dir. Uygun dalga boyuna yakın kızılötesi 1şığa maruz bırakılan NS, içinde bulunduğu hücreyi öldürebilecek, fakat etraftaki sağlıklı hücrelere zarar vermeyecek derecede 1S1 yayacaktır. Aynı zamanda, NS'lerin yüzeyine ilgili kansere yönelik antikor ve/ veya antikanser ilaçlar yerleştirilerek kanserli hücrelerin saptanması ya da tedavi edilmesi mümkün olabilecektir (Nehru ve Singh 2008).

\section{NANOTEKNOLOJININ OLASI ZARARLARI}

Nanoteknoloji alanındaki gelişmelere paralel olarak ortaya çıkan yeni uygulamaların insan yaşamına sağladığı/ sağlayacağı katkı oldukça önemlidir. Ancak, nanoteknoloji ürünlerinin kısa ve uzun dönemde insan sağlığı ve çevreye verebileceği olumsuz etkilerinin ortaya konulması, nanoteknolojik gelişmeler kadar önem taşımaktadır. Nano ürünlerin birçok alanda kullanılmaya başlamasına karşın, nanoteknolojinin olası zararlarına ilişkin literatür bilgisinin oldukça sınırlı olduğu ve insan sağlığı ya da çevreye olabilecek yan etki ve zararlarının tam olarak ortaya konulamadığı görülmektedir (Atl1-Şekeroğlu 2013; Kuzma 2010).

Nanopartiküller solunum, sindirim ve cilt yoluyla vücuda alınarak dolaşıma karışabilmektedir. Hangi yolla alınırsa alınsın, bu partiküllerin vücutta birçok organı etkileyerek bazı hastalıkların ortaya çıkmasına neden 
olabileceği vurgulanmaktadır (Atl1-Şekeroğlu 2013). Ayrıca, vücut içerisinde belli bölgelerde etki göstermesi amaçlanan nanopartiküllerin, vücudun amaç dış1 bölgelerine dağılmalarına bağlı olarak inflamatuvar ve toksik etki ortaya çıkarabilecekleri düşünülmektedir. Bu nedenle, nanopartiküllerin uygulama öncesinde genetik toksikoloji testleri ile olası yan etkilerinin kontrol edilmesi son derece önemlidir (Atl1-Şekeroğlu 2013; Gonzalez, Lison ve Kirsch-Volders 2008; Kocaefe 2007). Nanopartikülün genotoksik olması aynı zamanda karsinojenik olduğunu da göstermektedir. $\mathrm{Bu}$ nedenle, nanomateryallerin biyogüvenilirliğinin sağlanması insan sağlığı açısından son derece önemlidir (Atl1-Şekeroğlu 2013).

\section{SONUÇ VE ÖNERILER}

Sonuç olarak nanoteknoloji, birçok alanda olduğu gibi sağlık alanında da etkilerini göstermeye başlamıştır ve gelecek için de umut kaynağ 1 olarak görülmektedir. Ancak nanoteknolojinin, sağlik alanında etki ve yan etkilerinin henüz tam olarak açıklığa kavuşmamış olduğu görülmektedir. Nanoteknoloji alanında var olan ve olası gelişmelerin izlenmesi ve bilgilerin güncellenmesi, sağlı̆g 1 geliştirme ve koruma ile hasta bakım ve tedavi uygulamalarının gelişmesine katkı sağlayabileceği düşünülmektedir.

\section{KAYNAKLAR}

Atl1-Şekeroğlu, Z. (2013). Nanoteknolojiden nanogenotoksikolojiye: Kobalt-krom nanopartiküllerinin genotoksik etkisi. Türk Hijyen ve Deneysel Biyoloji Dergisi, 70(1): 33-42.

Bozkaya, Y. (2011). Nanoteknoloji ve uygulamaları. Anadolu Üniversitesi İleri Teknolojiler Araştırma Birimi, http://www.itab.anadolu.edu.tr/itab/pdf/nylp.pdf (05.07.2015).

Bölüktaş, R. P. (2015). Onkoloji alanında sonuç göstergesi olarak yaşam kalitesinin kullanımı. Can, G. (Ed.). Onkoloji Hemşireliği. Nobel Tip Kitabevleri, İstanbul, 95-109.

Celep, Ş., Koç, E. (2008). Nanoteknoloji ve tekstilde uygulama alanları. Ç. Ü. Fen Bilimleri Enstitüsü, 17(7): 43-52.

Çelik, S. (2011). Cerrahi bakımda bilgi güncelleme. Acıbadem Üniversitesi Să̆llk Bilimleri Dergisi, 2(2): 61-65.

Çıracı, S. ve ark. (2005). Türkiye'de nanoteknoloji. TÜBİTAK Bilim ve Teknik Dergisi Yeni Ufuklara, 2005(Ağustos): 3-23.
Çıracı, S. (2012). Ulusal Nanoteknoloji Araştırma Merkezi (UNAM) Malzeme Bilimi ve Nanoteknoloji Enstitüsü Bülteni, http://unam.bilkent.edu.tr/ (06.07.2015).

Dağ, A. (2014). Nanoteknolojinin gıdalara uygulanması ve sağlık üzerine etkisi. Beslenme ve Diyet Dergisi, 42(2): 168-174.

Erol-Demirbilek, M. (2015). Tarımda ve gıdada nanoteknoloji. Gıda ve Yem Bilimi-Teknolojisi Dergisi, 15(1): 46-53.

Gonzalez, L., Lison, D., Kirsch-Volders, M. (2008). Genotoxicity of engineered nanomaterials: A critical review. Nanotoxicol, 2(4): 252-273.

Karabacak, Ü., Uslu, Y. (2015). Onkoloji hastasında radyoterapi ve bakım. Can, G. (Ed.). Onkoloji Hemşireliği. Nobel Tıp Kitabevleri, İstanbul, 155-168.

Karateke, M., Güngör, E., Demir, A. (2010). Nanoteknoloji ve Tekstil Sektöründe Uygulamalar. MYO-ÖS 2010-Ulusal Meslek Yüksekokulları Öğrenci Sempozyumu, 21-22 Ekim, Düzce.

Kayır, Y. Z., Bağçıl, E. G. (2010). Nanoteknoloji Nedir? 15. Uluslararası Metalurji ve Malzeme Kongresi, 11-13 Kasım, İstanbul.

Kirson, E. D., Yaari, Y. (2000). A novel technique for microdissection of neuronal processes. Journal of Neuroscience Methods, 98(2): 119-122.

Kocaefe, Ç. (2007). NANOTIP: Yaşam bilimlerinde nanoteknoloji uygulamaları. Hacettepe Tip Dergisi, 38(1): 33-38.

Kumar, B., Yadav, P. R., Goel, H. C., Moshahid, M., Rizvi, A. (2009). Recent developments in cancer therapy by use of nanotechnology. Digest Journal of Nanomater Biostructures, 4(1): 1-12.

Kuruca, B. (2012). Nanotıp ve nanoteknoloji. Net Bilim Dergisi, 14(1): 17-23.

Kuzma, J., Priest, S. (2010). Nanotechnology, risk, and oversight: Learning lessons from related emerging technologies. Risk Analysis, 30(11): 1688-1698.

Laiva, A. ve ark. (2015). Controlled release of titanocene into the hybrid nanofibrous scaffolds to prevent the proliferation of breast cancer cells. International Journal of Pharmaceutics, 483(1): 115-123.

Langer, R., Weissleder, R. (2015). Nanotechnology. JAMA, 313(2): 135-136.

Luo, Y., Pan, K., Zhong, Q. (2015). Casein/pectin nanocomplexes as potential oral delivery vehicles. International Journal of Pharmaceutics, 486(1): 59-68.

Meng, H. ve ark. (2013). Two-wave nanotherapy to target the stroma and optimize gemcitabine delivery to a human pancreatic cancermodel in mice. ACS Nano, 7(11): 10048-10065.

Mousavie-Anijdan, S. H., Mahdavi, S. R., Shirazi, A., Zarrinfard, M. A., Haiati, J. (2013). Megavoltage x-ray dose enhancement with gold nanoparticles in tumor bearing mice. International Journal of Molecular and Cellular Medicine, 2(3): 118-123. 
Nahcivan, N. O., Seçginli, S. (2015). Kanserde tarama ve erken tanı. Can, G. (Ed.). Onkoloji Hemşireliği. Nobel Tıp Kitabevleri, İstanbul, 41-58.

Narter, F. (2005). Nanotıp ve biomateryaller: Androlojide olası kullanım alanları. Androloji Bülteni, 22(1): 196-200.

Nehru, M. R., Singh, P. O. (2008). Nanotechnology and cancer treatment. Asian J. Exp. Sci., 22(2): 45-50.

Neumaier, C. E., Baio, G., Ferini, S., Corte, G., Daga, A. (2008). Mr and iron magnetic nanoparticles: Imaging oportunities in preclinical and translational reserch. Tumori, 94(2): 226-233.

Oylar, Ö., Tekin, İ. (2011). Kanser teşhis ve tedavisinde nanoteknolojinin önemi. Uludağ Üniversitesi Mühendislik-Mimarlık Fakültesi Dergisi, 16(1): 147-154.

Roberts, A., Freitas, J. R. (2005a). Nanotechnology, nanomedicine and nanosurgery. International Journal of Surgery, 3(4): 243-246.

Roberts, A., Freitas, J. R. (2005b). What is nanomedicine? Nanomedicine: Nanotechnology, Biology and Medicine, 1(1): 2-9.

Sanna, V., Pala, N., Sechi, M. (2014). Targeted therapy using nanotechnology: Focus on cancer. International Journal of Nanomedicine, 15(9): 467-483.

Singh, K. K. (2005). Nanotechnology in cancer detection and treatment. Technology in Cancer Research and Treatment, 4(6): 583-584.

Syed, S., Zubair, A., Frieri, M. (2013). Immune response to nanomaterials: Implications for medicine and literature review. Curr Allergy Asthm Rep, 13(1): 50-57.
Şenel, F. (2009). Nanotıp. Bilim ve Teknik, 497(1): 79-83.

Turgut, O., Keskin, H. L., Avşar, A. F. (2010). Nanoteknoloji nedir? Türk Tıp Dergisi, 5(1): 45-49.

Tarhan, Ö., Gökmen, V., Harsa, Ş. (2010). Nanoteknolojinin gida bilim ve teknolojisi alanındaki uygulamaları. Gıda Dergisi, 35(3): 219-225.

Toksöz, S., Güler, M. O. (2009). Self-assembled peptidic nanostructures. Nano Today, 4(6): 458-469.

Ünlü, H. (2009). Nanobilim ve nanoteknoloji. İstanbul Teknik Üniversitesi Fizik Bölümü, Nanoyapı Yarı İletken Araştırma Laboratuarı, http://maycalistaylari.comu.edu.tr/calistay2009/sunumlar/ konferans/Hunlu_NanTek.pdf (25.06.2015).

Üreyen, M. E. (2007). Nanoteknoloji ve Türk tekstil ve hazır giyim sektörleri, http://www.nano.bilkent.edu.tr/Basin/ NanoTekstil.pdf (10.03.2015).

Wang, L. V. (2004). Ultrasound-mediated biophotonic imaging: A review of acouto-optical tomography and photo-acoustic tomography. Disease Markers, 19(2): 123-138.

Wang, A. Z., Tepper, J. E. (2014). Nanotechnology in radiation oncology. Journal of Clinical Oncology, 32(26): 2879-2885.

Yıldı, İ. (2015). Sitotoksik kemoterapi prensipleri. Can, G. (Ed.). Onkoloji Hemşireliği. Nobel Tıp Kitabevleri, İstanbul, 169-190.

Yula, E., Deveci, Ö. (2010). Nanotıp, mikrodizilimler ve klinik mikrobiyolojide kullanımları. Dicle Tip Dergisi, 37(4): 422-428. 